\title{
Thrombin Stimulates Synthesis of Macrophage Colony-Stimulating Factor, Granulocyte-Macrophage Colony- Stimulating Factor and Granulocyte Colony-Stimulating Factor by Human Proximal Tubular Epithelial Cells in Culture
}

\author{
Yuko Shimaya Michiko Shimada Yoshiko Shutto \\ Takeshi Fujita Reiichi Murakami Norio Nakamura \\ Hideaki Yamabe Ken Okumura \\ Hirosaki University, Graduate School of Medicine, Division of Cardiology, Respiratory Medicine \\ and Nephrology, Hirosaki, Japan
}

\section{Key Words}

Thrombin $\cdot$ Inflammatory cytokines $\cdot$ Tubular epithelial cells $\cdot$ Colony-stimulating factors

\begin{abstract}
Background/Aims: Colony-stimulating factors (CSFs) are well-known hematopoietic growth factors. Although recent studies revealed that CSFs are involved in many inflammatory conditions, the local production of CSFs and its regulation in the kidney is not well elucidated. Therefore, using cultured human proximal tubular epithelial cells (PTEC), we examined the effect of thrombin on CSFs production, since thrombin has been suggested to play an important role in tubulointerstitial injury. Methods: PTEC were incubated with thrombin $(0.5-5.0 \mathrm{U} / \mathrm{ml})$ and the effects on the production of macrophage CSF (M-CSF), granulocyte-macrophage CSF (GM-CSF) and granulocyte CSF (G-CSF) were measured in the cell supernatant by enzyme-linked immunosorbent assay, and the expressions of mRNA were analyzed by quantitative real-time reverse transcription polymerase chain reaction. Using argatroban, a direct thrombin inhibitor, we also examined the specific effect of thrombin. Results: Thrombin $5.0 \mathrm{U} / \mathrm{ml}$ significantly stimulated the production of M-CSF $(p<0.01)$ and G-CSF $(p<0.01)$, and 1.0 and $5.0 \mathrm{U} / \mathrm{ml}$ thrombin signifi-
\end{abstract}


cantly stimulated GM-CSF $(p<0.02$ and $p<0.01)$ in a dose-dependent manner. Thrombin 5.0 $\mathrm{U} / \mathrm{ml}$ increased CSFs (M-CSF, $\mathrm{p}<0.005$; GM-CSF, $\mathrm{p}<0.0005$; G-CSF, $\mathrm{p}<0.005$ ) in a time-dependent manner. Thrombin also significantly enhanced the mRNA expressions of M-CSF $(p<0.01)$, GM-CSF $(p<0.05)$ and G-CSF $(p<0.01)$. These effects of thrombin were significantly reduced by the addition of argatroban (M-CSF, $p<0.01$; GM-CSF, $p<0.01$; G-CSF, $p<0.05$ ). Conclusion: We demonstrated that thrombin significantly increased the production of CSFs by PTEC. These data suggest that the local production of CSFs in the tubulointerstitium may affect tubulointerstitial lesions in kidney injury.

Copyright $\odot 2012$ S. Karger AG, Basel

\section{Introduction}

Macrophage colony-stimulating factor (M-CSF), granulocyte-macrophage CSF (GM$\mathrm{CSF}$ ) and granulocyte CSF (G-CSF) are well-known hematopoietic growth factors. However, recent studies revealed that CSFs act not only on hematopoietic cells but on various cell types and are involved in many inflammatory conditions. CSFs are suggested to exacerbate autoimmune-mediated inflammatory diseases including systemic lupus erythematosus and rheumatoid arthritis. Currently, the efficacy of an antagonist of GM-CSF is under clinical trials as a new therapeutic option for rheumatoid arthritis [1].

Some evidence suggested harmful effects of CSFs in the kidney. In MRL-Fas lpr mice, urine M-CSF levels correlated with lupus activity, and lupus nephritis was reduced by systemic depletion of M-CSF [2]. Furthermore, in an experimental antiglomerular membrane glomerulonephritis model, both glomerular lesions and tubulointerstitial lesions were attenuated in GM-CSF knockout mice compared with the wild type. In this model, the authors suggested the critical role of locally produced GM-CSF [3]. However, there is some evidence showing that G-CSF could be protective. G-CSF accelerated the recovery from acute tubular injury from cisplatin-induced acute kidney injury by accelerating regeneration and by preventing apoptosis of renal tubular cells [4]. However, the knowledge about the local production of CSFs and its regulation in the kidney is very limited.

Tubulointerstitial damage plays a pivotal role in progressive renal injury. Fibrin deposition is commonly observed in the peritubular capillaries and along the tubular basement membrane in tubulointerstitial damage in various renal diseases, including obstructive nephropathy, experimental lupus nephritis, ischemic tubular necrosis and chronic allograft nephropathy [5-11]. Thrombin which is generated in the process of fibrin formation has been detected in the urine of patients with glomerulonephritis [12]. Recent evidence suggests that thrombin also induces various inflammatory responses in addition to its role in blood coagulation [13]. Thus, thrombin is suggested as one of the pathogenic mediators in tubulointerstitial injury.

In this study, we hypothesized that local expression of CSFs in the kidney may be increased in tubulointerstitial injury, and using cultured human proximal tubular epithelial cells (PTEC), we examined CSFs production stimulated by thrombin.

\section{Methods}

\section{Cell Culture}

Primary human PTEC were purchased from BioWhittaker (Walkersville, Md., USA). The cells were cultured with Renal Epithelial Cell Growth Medium BulletKit (REBM) supplemented with $5 \mu \mathrm{g} / \mathrm{ml}$ insulin, $10 \mu \mathrm{g} / \mathrm{ml}$ transferrin, $0.5 \mu \mathrm{g} / \mathrm{ml}$ hydrocortisone, $6.5 \mathrm{ng} / \mathrm{ml}$ 
trio-iodothyronine, $0.5 \mu \mathrm{g} / \mathrm{ml}$ epinephrine, $10 \mathrm{ng} / \mathrm{ml}$ epidermal growth factor and $0.5 \%$ heat-inactivated fetal bovine serum (all from BioWhittaker) at $37^{\circ} \mathrm{C}$ in $5 \% \mathrm{CO}_{2}$. PTEC between passages 4 and 5 were used for the experiments.

Assay of M-CSF, GM-CSF and G-CSF

M-CSF, GM-CSF and G-CSF were quantified by an enzyme-linked immunosorbent assay (ELISA) using the Immunoassay Kit (R\&D, O'Fallon, Mo., USA). This assay is a sandwich ELISA using an antibody original for human M-CSF, GM-CSF and G-CSF. No significant cross-reactivity with other cytokines was observed.

PTEC were cultured in 12-well plates (Becton Dickinson, Franklin Lakes, N.J., USA). Confluent cells were washed twice with Hanks' balanced salt solution (Gibco Laboratories, Grand Island, N.Y., USA) and incubated with Dulbecco's modified Eagle's minimum essential medium (DMEM, Gibco Laboratories) containing $0.2 \%$ bovine serum albumin (BSA; Sigma, St. Louis, Mo., USA) for 24, 48, or $72 \mathrm{~h}$. Then the levels of M-CSF, GM-CSF and GCSF were measured in the culture supernatant. After removing the culture supernatant, the cells in each well were dissolved in $1 \mathrm{~N} \mathrm{NaOH}$ and the protein content was measured by the method of Lowry et al. [14] using BSA as the standard. Then the levels of M-CSF, GM-CSF and G-CSF were expressed as picograms per microgram of PTEC protein.

\section{Quantitative Reverse-Transcription Polymerase Chain Reaction}

Confluent PTEC cultured in 6-well plates (Becton Dickinson) were incubated with DMEM containing $0.2 \%$ BSA with or without thrombin $(5.0 \mathrm{U} / \mathrm{ml})$ for $6 \mathrm{~h}$. The expression of M-CSF, GM-CSF and G-CSF mRNA in PTEC was quantified by real-time reverse transcription polymerase chain reaction (RT-PCR). Total RNA was extracted from the cells using an RNeasy Protect Mini Kit (QIAGEN, Valencia, Calif., USA). The RNA was transcribed into first-strand cDNA with an Omniscript RT kit (QIAGEN). Quantitative RT-PCR was performed using an ABI PRISM 7700 Sequence Detector (PE Applied Biosystems, Foster City, Calif., USA). Specific primers for human M-CSF (Hs99999083_m1), GM-CSF (Hs00929873_ m1), G-CSF (Hs99999084_m1) and GAPDH (Hs99999905_m1) were obtained from Applied Biosystems. The relative expression levels of M-CSF, GM-CSF and G-CSF mRNA in the samples were normalized by GAPDH mRNA.

\section{Stimulation of M-CSF, GM-CSF and G-CSF Production with Thrombin}

Confluent PTEC cultured in 12-well plates (Becton Dickinson) were incubated with DMEM containing 0.2\% BSA containing 0.5-5.0 U/ml $\alpha$-thrombin (Sigma) for $72 \mathrm{~h}$. Then we measured M-CSF, GM-CSF and G-CSF in the supernatant of PTEC to determine the dose effect of thrombin. The time effect of thrombin was also examined by incubating PTEC with or without $5.0 \mathrm{U} / \mathrm{ml}$ thrombin for 24,48 , and $72 \mathrm{~h}$. In addition, we also examined the inhibitory effect of argatroban, a synthetic thrombin inhibitor (Mitsubishi Kasei Corporation, Tokyo, Japan). PTEC were incubated for $72 \mathrm{~h}$ with $5.0 \mathrm{U} / \mathrm{ml}$ thrombin alone, $5.0 \mathrm{U} / \mathrm{ml}$ thrombin plus argatroban $(1 \mu \mathrm{mol})$, or argatroban $(1 \mu \mathrm{mol})$ alone. Then M-CSF, GM-CSF and GCSF were measured in the culture supernatant.

We estimated the cytotoxicity of thrombin and argatroban to the PTEC used in this experiment. PTEC were incubated in 24-well plates (Becton Dickinson) for $24 \mathrm{~h}$, and the lactate dehydrogenase (LDH) levels in the cell supernatant were measured. After removing the cell supernatant, PTEC were lysed by melittin ( $50 \mu \mathrm{g} / \mathrm{ml}$, Sigma) and the LDH levels in the cell lysates were also measured. LDH was quantified by a colorimeter using an LDH assay kit (Sanassay LDH; Sankou-Junyaku, Inc., Tokyo, Japan). There was no significant release of LDH from PTEC and we thought the concentrations of thrombin and argatroban which we used in this experiment showed no cytotoxicity. 

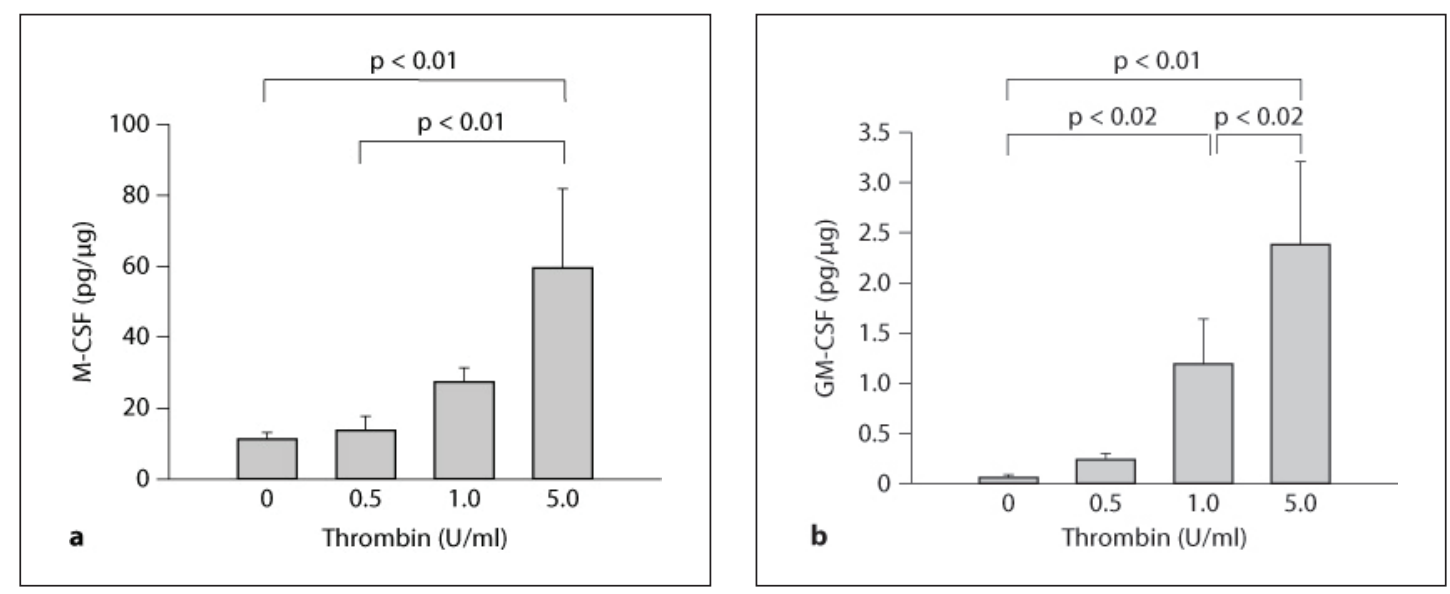

Fig. 1. Effect of thrombin on M-CSF (a), GM-CSF (b) and G-CSF (c) production in PTEC. PTEC were incubated with thrombin $(0-5.0 \mathrm{U} / \mathrm{ml})$ for $72 \mathrm{~h}$ and the cell supernatant was quantified by ELISA.

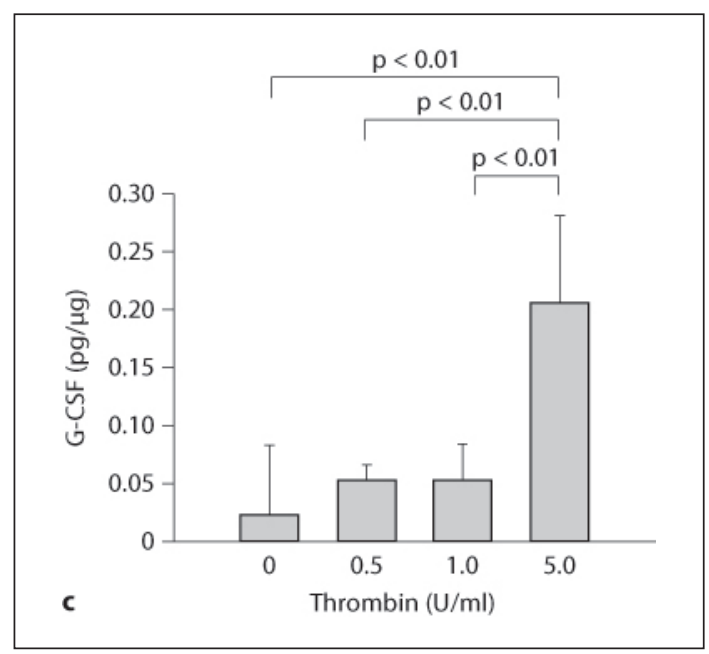

\section{Statistical Analysis}

All data are expressed as mean \pm 1 standard deviation. Results were compared using the one-way factorial ANOVA and multiple comparison tests for the dose effect of thrombin and the effect of argatroban, the two-way repeated-measures ANOVA for the time effect of thrombin, and the unpaired $t$ test for the quantification of mRNA. $p<0.05$ was considered significant.

\section{Results}

Thrombin Stimulates the Production of M-CSF, GM-CSF and G-CSF in PTEC

PTEC were incubated with or without thrombin for $72 \mathrm{~h}$. The mean level of M-CSF from three wells was $11.20 \pm 1.90 \mathrm{pg} / \mu \mathrm{g}$ protein at thrombin $0 \mathrm{U} / \mathrm{ml}, 13.70 \pm 3.98 \mathrm{pg} / \mu \mathrm{g}$ protein at thrombin $0.5 \mathrm{U} / \mathrm{ml}, 27.33 \pm 4.03 \mathrm{pg} / \mu \mathrm{g}$ protein at thrombin $1.0 \mathrm{U} / \mathrm{ml}$, and 59.53 $\pm 22.36 \mathrm{pg} / \mu \mathrm{g}$ protein at thrombin $5.0 \mathrm{U} / \mathrm{ml}$ (fig. 1a). The mean level of GM-CSF from three wells was $0.06 \pm 0.03 \mathrm{pg} / \mu \mathrm{g}$ protein at thrombin $0 \mathrm{U} / \mathrm{ml}, 0.24 \pm 0.06 \mathrm{pg} / \mu \mathrm{g}$ protein at thrombin $0.5 \mathrm{U} / \mathrm{ml}, 1.19 \pm 0.45 \mathrm{pg} / \mu \mathrm{g}$ protein at thrombin $1.0 \mathrm{U} / \mathrm{ml}$, and $2.38 \pm 0.83 \mathrm{pg} / \mu \mathrm{g}$ protein at thrombin $5.0 \mathrm{U} / \mathrm{ml}$ (fig. 1b). The mean level of G-CSF from three wells was 0.023 $\pm 0.006 \mathrm{pg} / \mu \mathrm{g}$ protein at thrombin $0 \mathrm{U} / \mathrm{ml}, 0.053 \pm 0.013 \mathrm{pg} / \mu \mathrm{g}$ protein at thrombin 

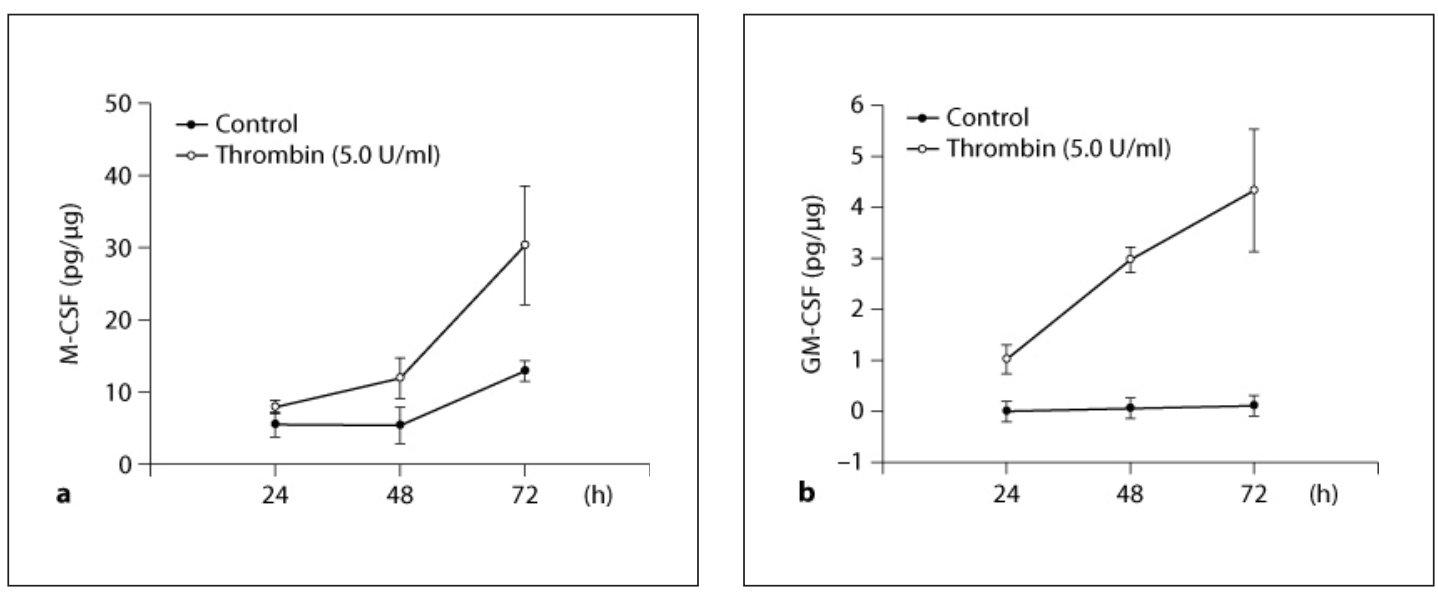

Fig. 2. Time course of the effect of thrombin on MCSF (a), GM-CSF (b) and G-CSF (c) production in PTEC. PTEC were incubated in the absence of thrombin (control) or with $5.0 \mathrm{U} / \mathrm{ml}$ thrombin for 24-72 $\mathrm{h}$ and the cell supernatant was quantified by ELISA. Results were compared using the repeatedmeasures ANOVA. Thrombin stimulated the production of M-CSF ( $\mathrm{p}<0.005)$, GM-CSF ( $<<$ $0.0005)$ and G-CSF $(\mathrm{p}<0.05)$ in a time-dependent manner.

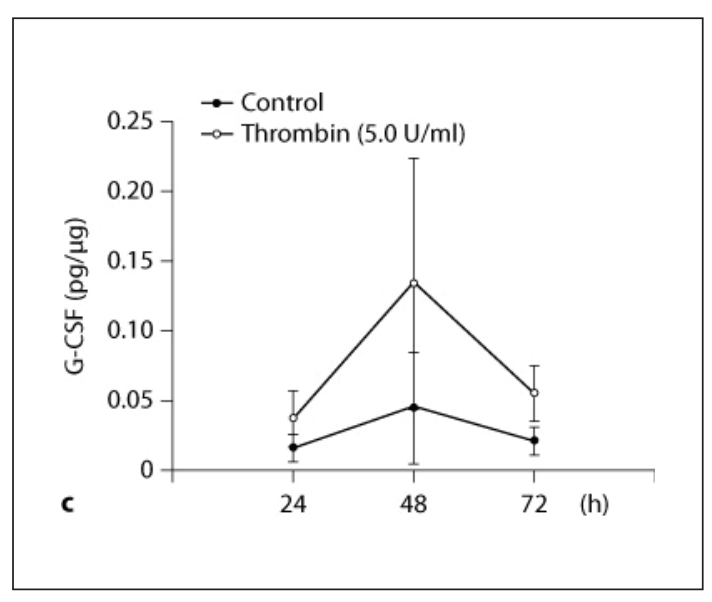

$0.5 \mathrm{U} / \mathrm{ml}, 0.053 \pm 0.031 \mathrm{pg} / \mu \mathrm{g}$ protein at thrombin $1.0 \mathrm{U} / \mathrm{ml}$, and $0.206 \pm 0.075 \mathrm{pg} / \mu \mathrm{g}$ protein at thrombin $5.0 \mathrm{U} / \mathrm{ml}$ (fig. 1c). Thrombin $5.0 \mathrm{U} / \mathrm{ml}$ significantly increased M-CSF (p < $0.01)$ and G-CSF $(\mathrm{p}<0.01)$. Thrombin $1.0 \mathrm{U} / \mathrm{ml}$ and $5.0 \mathrm{U} / \mathrm{ml}$ significantly increased GMCSF ( $p<0.02$ and $\mathrm{p}<0.01$, respectively; $1.0 \mathrm{U} / \mathrm{ml}$ vs. $5.0 \mathrm{U} / \mathrm{ml}: \mathrm{p}<0.02)$ in a dose-dependent manner.

The time effect of thrombin was also examined by incubating PTEC with or without 5.0 $\mathrm{U} / \mathrm{ml}$ thrombin for 24,48 , and $72 \mathrm{~h}$. Thrombin significantly stimulated the production of M-CSF ( $p<0.005$, fig. 2a), GM-CSF ( $<<0.0005$, fig. $2 b)$ and G-CSF $(p<0.05$, fig. $2 c$ ) in a time-dependent manner.

\section{Inhibitory Effect of Argatroban on Thrombin-Induced Production of M-CSF, GM-CSF and $G-C S F$}

PTEC were incubated with thrombin $5.0 \mathrm{U} / \mathrm{ml}$ with or without argatroban $1 \mu \mathrm{mol}$ for $72 \mathrm{~h}$. Argatroban significantly inhibited the increased production of M-CSF ( $<<0.01)$, GMCSF $(\mathrm{p}<0.01)$ and G-CSF $(\mathrm{p}<0.05)$ by thrombin (fig. 3$)$.

\section{Thrombin Stimulates mRNA Expressions of M-CSF, GM-CSF and G-CSF}

PTEC were incubated with thrombin $5 \mathrm{U} / \mathrm{ml}$ for $6 \mathrm{~h}$. The mRNA expressions of M-CSF ( $p<0.01$, fig. 4a), GM-CSF ( $p<0.05$, fig. 4b) and G-CSF ( $p<0.01$, fig. 4c) were significantly increased compared with control. 


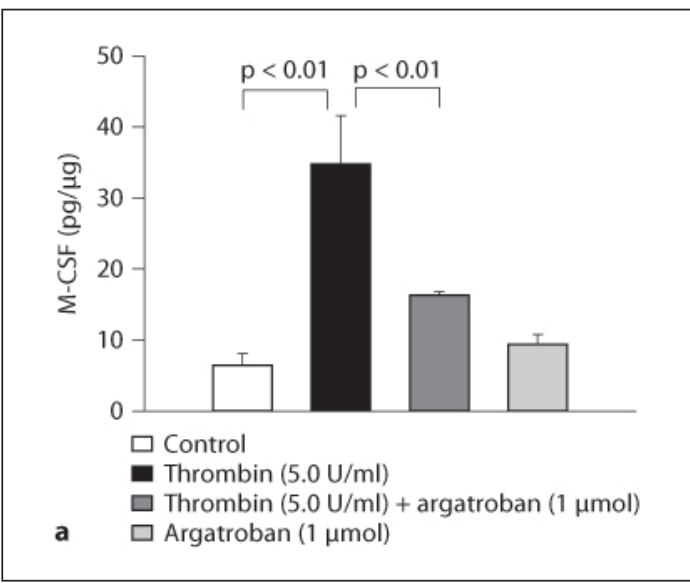

Fig. 3. Effect of argatroban on thrombin-induced M-CSF (a), GM-CSF (b) and G-CSF (c) production in PTEC. PTEC were incubated with argatroban $(1 \mu \mathrm{M})$ with or without thrombin $(5.0 \mathrm{U} / \mathrm{ml})$ for $72 \mathrm{~h}$ and the cell supernatant was quantified by ELISA.
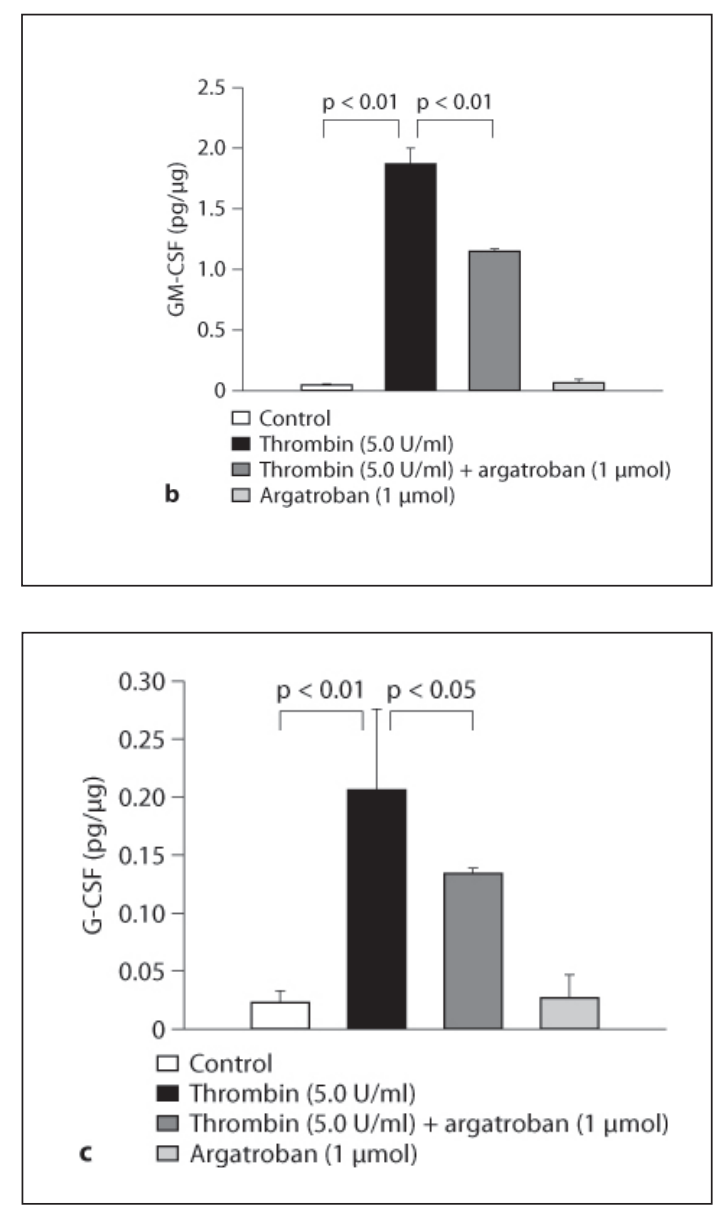

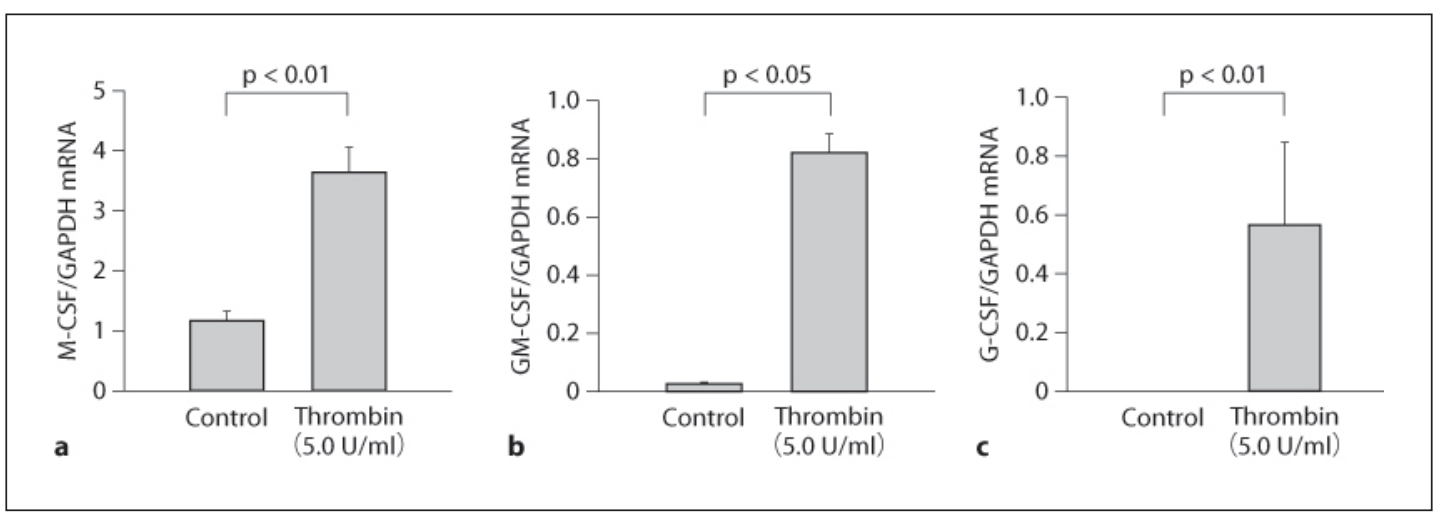

Fig. 4. Effect of thrombin on mRNA expression of M-CSF (a), GM-CSF (b) and G-CSF (c) in PTEC. PTEC were incubated with thrombin $(5.0 \mathrm{U} / \mathrm{ml})$ for $6 \mathrm{~h}$.

\section{Discussion}

Thrombin has various biological effects besides blood coagulation and induces various inflammatory cytokines including IL-6 [15] and TNF- $\alpha$ [16] via the main thrombin receptor proteinase activated receptor-1 (PAR-1). The effect of thrombin on tubular cells is not fully 
understood. It was, however, shown that tubular cells express PAR-1 and its expression was strikingly increased in accordance with the severity of chronic allograft nephropathy [17]. We have also reported that thrombin stimulates fibronectin production in human PTEC via TGF- $\beta$-dependent mechanism and suggested that thrombin is a pivotal factor in tubulointerstitial fibrosis.

There is some evidence that kidney cells produce CSFs. Cultured human PTEC express GM-CSF when stimulated with heat-inactivated Escherichia coli as shown by immunostaining [18]. Besides, M-CSF expression by immunostaining in tubular epithelial cells was increased and its expression level correlated with the activity index of lupus nephritis [2]. Furthermore, mesangial cells produce GM-CSF as shown by Northern blotting [3, 19]. In this study, we proved that PTEC were capable of producing M-CSF, GM-CSF and G-CSF when stimulated with thrombin.

It is not known how tubular CSFs work in the kidney. However, it is well known that the infiltration of inflammatory cells, such as macrophages [20] or granulocytes, is an important feature of tubulointerstitial injury. Importantly, recent evidence suggests that the phenotype of the macrophage is of great importance. GM-CSF induces activated macrophages (M1) which are involved in inflammation and host defense, and M-CSF promotes alternatively activated macrophages (M2) with an anti-inflammatory and tissue repair phenotype [1]. Interestingly, it was suggested that the macrophage phenotype could be altered in the tubulointerstitium in the kidney. Therefore, we speculate that tubular CSFs may be involved in tubulointerstitial injury, possibly via the increased amount of infiltrated cells and their inflammatory phenotype. Obviously, we need further studies to elucidate the role of local CSFs expression in the pathophysiology of the tubulointerstitium in the kidney.

In conclusion, we demonstrated that thrombin induced the expressions of M-CSF, GMCSF and G-CSF in PTEC, which was proved by ELISA for protein expression and by quantitative RT-PCR for mRNA expression. Its effect was significantly reduced by the direct thrombin inhibitor argatroban, suggesting the specific effect of thrombin. These changes may affect the pathogenesis of tubulointerstitial injury in the kidney.

\section{References}

1 Cornish AL, Campbell IK, McKenzie BS, Chatfield S, Wicks IP: G-CSF and GM-CSF as therapeutic targets in rheumatoid arthritis. Nat Rev Rheumatol 2009;5:554-559.

-2 Menke J, Rabacal WA, Byrne KT, Iwata Y, Schwartz MM, Stanley ER: Circulating CSF-1 promotes monocyte and macrophage phenotypes that enhance lupus nephritis. J Am Soc Nephrol 2009;20: 2581-2592.

-3 Timoshanko JR, Kitching AR, Semple TJ, Holdsworth SR, Tipping PG: Granulocyte macrophage colony-stimulating factor expression by both renal parenchymal and immune cells mediates murine crescentic glomerulonephritis. J Am Soc Nephrol 2005;16:2646-2656.

-4 Nishida M, Fujimoto S, Toiyama K, Sato H, Hamaoka K: Effect of hematopoietic cytokines on renal function in cisplatin-induced ARF in mice. Biochem Biophys Res Commun 2004;324:341-347.

-5 Pontrelli P, Ranieri E, Ursi M, Ghosh-Choudhury G, Paolo Schena F, Grandaliano G: jun-N-terminal kinase regulates thrombin-induced PAI-1 gene expression in proximal tubular epithelial cells. Kidney Int 2004;65:2249-2261.

-6 Yamamoto K, Loskutoff DJ: The kidneys of mice with autoimmune disease acquire a hypofibrinolytic/procoagulant state that correlates with the development of glomerulonephritis and tissue microthrombosis. Am J Pathol 1997;151:725-734.

7 Enestrom S, Druid H, Rammer L: Fibrin deposition in the kidney in post-ischaemic renal damage. Br J Exp Pathol 1988;69:387-394. 
8 Faulk WP, Gargiulo P, McIntyre JA: Hemostasis and fibrinolysis in renal transplantation. Semin Thromb Hemost 1989;15:88-98.

-9 Wang Y, Pratt JR, Tam FW, Hartley B, Wolff JA, Olavesen MG, et al: Up-regulation of type 1 plasminogen activator inhibitor messenger RNA with thrombotic changes in renal grafts. Transplantation 1996;61:684-689.

-10 Wang Y, Pratt JR, Hartley B, Evans B, Zhang L, Sacks SH: Expression of tissue type plasminogen activator and type 1 plasminogen activator inhibitor, and persistent fibrin deposition in chronic renal allograft failure. Kidney Int 1997;52:371-377.

-11 Wendt T, Zhang YM, Bierhaus A, Kriegsmann J, Deng Y, Waldherr R, et al: Tissue factor expression in an animal model of hydronephrosis. Nephrol Dial Transplant 1995;10:1820-1828.

-12 Lwaleed BA, Bass PS, Chisholm M, Francis JL: Urinary tissue factor in glomerulonephritis: a potential marker of glomerular injury? J Clin Pathol 1997;50:336-340.

-13 Shirato K, Osawa H, Kaizuka M, Nakamura N, Sugawara T, Nakamura M, et al: Thrombin stimulates production of fibronectin by human proximal tubular epithelial cells via a transforming growth factor-beta-dependent mechanism. Nephrol Dial Transplant 2003;18:2248-2254.

- 14 Lowry O, Rosebrough NJ, Farr AL: Protein measurement with the Froin phenol reagent. J Biol Chem 1951;193:265-275.

-15 Pagel CN, Song SJ, Loh LH, Tudor EM, Murray-Rust TA, Pike RN, et al: Thrombin-stimulated growth factor and cytokine expression in osteoblasts is mediated by protease-activated receptor-1 and prostanoids. Bone 2009;44:813-821.

-16 Chieng-Yane P, Bocquet A, Letienne R, Bourbon T, Sablayrolles S, Perez M, et al: Protease-activated receptor-1 antagonist $\mathrm{F} 16618$ reduces arterial restenosis by down-regulation of tumor necrosis factor alpha and matrix metalloproteinase 7 expression, migration, and proliferation of vascular smooth muscle cells. J Pharmacol Exp Ther 2011;336:643-651.

-17 Grandaliano G, Di Paolo S, Monno R, Stallone G, Ranieri E, Pontrelli P, et al: Protease-activated receptor 1 and plasminogen activator inhibitor 1 expression in chronic allograft nephropathy: the role of coagulation and fibrinolysis in renal graft fibrosis. Transplantation 2001;72:1437-1443.

- 18 Brauner A, Soderhall M, Jacobson SH, Lundahl J, Andersson U, Andersson J: Escherichia coli-induced expression of IL-1 alpha, IL-1 beta, IL-6 and IL-8 in normal human renal tubular epithelial cells. Clin Exp Immunol 2001;124:423-428.

19 Budde K, Coleman DL, Lacy J, Sterzel RB: Rat mesangial cells produce granulocyte-macrophage colony-stimulating factor. Am J Physiol 1989;257:F1065-F1078.

-20 Ricardo SD, van Goor H, Eddy AA: Macrophage diversity in renal injury and repair. J Clin Invest 2008;118:3522-3530. 